\title{
PENGARUH KOMITMEN ORGANISASI, KEPUASAN KERJA DAN STRES KERJA TERHADAP KINERJA GURU DI SEKOLAH MENENGAH ATAS YPI AMIR HAMZAH MEDAN
}

\author{
${ }^{1}$ Sufriady Halomoan Hasibuan, ${ }^{2}$ Suhandi, ${ }^{3}$ Said Zainal Abidin, ${ }^{4}$ Muzakkir, ${ }^{5}$ Koko Nugroho \\ $1,2,3,4,5$ Universitas Islam Sumatera Utara \\ ${ }^{1}$ sufriady.halomoan@gmail.com, ${ }^{2}$ suhandi.mm@gmail.com, ${ }^{3}$ said.zainal@gmail.com, \\ ${ }^{4}$ muzakkir.mm@gmail.com, ${ }^{5}$ koko.nugroho@gmail.com
}

\begin{abstract}
This study aims to determine the effect of Organizational Commitment (X1), Job Satisfaction (X2) and Job Stress (X3) on Teacher Performance (Y) both partially and simultaneously at YPI Amir Hamzah High School Medan. This study uses a quantitative approach using a population and a sample of 48 teachers or respondents. The data collection techniques used are observation, interviews, questionnaires and documentation. The data analysis method used is Multiple Linear Regression Analysis. The results of the Multiple Linear Regression test partially show that Organizational Commitment with a significant value of 0.001, Job Satisfaction with a significant value of 0.027 and Job Stress with a significant value of 0.001 have a significant effect on teacher performance. In a simultaneous test, all independent variables have a significant effect on teacher performance, with a significant value of $0.000<0.05$. It can be concluded that organizational commitment, job satisfaction and job stress have a significant effect on teacher performance at YPI Amir Hamzah High School Medan.
\end{abstract}

Keywords : Organizational Commitment, Job Satisfaction, Job Stress and Teacher Performance

ABSTRAK : Penelitian ini bertujuan untuk mengetahui pengaruh Komitmen Organisasi (X1), Kepuasan Kerja (X2) dan Stres Kerja (X3) terhadap Kinerja Guru (Y) baik secara uji parsial maupun simultan di Sekolah Menengah Atas YPI Amir Hamzah Medan. Penelitian ini menggunakan pendekatan kuantitatif dengan menggunakan populasi dan sampel sebanyak 48 guru atau responden. Adapun teknik pengumpulan data yang digunakan adalah observasi, wawancara, kuesioner dan dokumentasi. Metode analisis data yang digunakan adalah Analisis Regresi Linear berganda. Hasil Penelitian uji Regresi Linear Berganda secara parsial menunjukkan bahwa Komitmen Organisasi dengan nilai signifikan 0.001, Kepuasan Kerja dengan nilai signifikan 0.001 dan Stres Kerja dengan nilai signifikan 0.027 maka berpengaruh secara signifikan terhadap kinerja guru. Secara uji simultan, keseluruhan variabel independen memiliki pengaruh signifikan terhadap kinerja guru yaitu dengan nilai signifikan 0,000 <0,05. Dapat disimpulkan bahwa Komitmen Organisasi, Kepuasan Kerja dan Stres Kerja berpengaruh signifikan terhadap Kinerja Guru di Sekolah Menengah Atas YPI Amir Hamzah Medan.

Kata Kunci : Komitmen Organisasi, Kepuasan Kerja, Stres Kerja dan Kinerja Guru

\section{Pendahuluan}

Kinerja guru merupakan elemen penting dalam pendidikan, selain itu juga merupakan penentu tinggi rendahnya kualitas pendidikan. Kualitas kinerja guru sangat menentukan pada kualitas hasil pendidikan dikarenakan guru merupakan sosok yang paling sering berinteraksi secara langsung dengan siswa pada saat proses pembelajaran.
Upaya untuk mencapai target dan tujuan pendidikan, sangat membutuhkan Sumber Daya Manusia yang kompeten dalam kinerjanya yaitu dalam hal ini dimaksudkan adalah para guru sebagai tenaga pendidik. Dengan demikian, tidak dapat dipungkiri bahwa kinerja guru menjadi sorotan penting bagi setiap sekolah tanpa terkecuali di SMA YPI Amir Hamzah Medan. Sebagai salah satu lembaga pendidikan yang berkiprah dalam mencerdaskan anak 
bangsa, tentunya memerlukan guru yang profesional dan ahli dalam bidangnya sehingga mampu memberikan kinerja yang optimal.
Berikut ini adalah data penilaian prestasi kinerja guru di YPI Amir Hamzah Medan selama tiga Tahun terakhir :

Tabel 1. Hasil Penilaian Kinerja Guru YPI Amir Hamzah Medan

\begin{tabular}{|l|c|c|c|c|c|c|}
\hline \multirow{2}{*}{ Indikator } & \multicolumn{2}{|c|}{ Tahun 2018 } & \multicolumn{2}{c|}{ Tahun 2019 } & \multicolumn{2}{c|}{ Tahun 2020 } \\
\cline { 2 - 7 } & $\mathbf{( \% )}$ & Ket. & $\mathbf{( \% )}$ & Ket. & $\mathbf{( \% )}$ & Ket. \\
\hline Pencapian Target & 75 & Cukup & 80 & Baik & 76 & Baik \\
\hline Kualitas Kerja & 85 & Baik & 80 & Baik & 80 & Baik \\
\hline Kecepatan Kerja & 90 & Baik & 73 & Cukup & 80 & Baik \\
\hline Keterampilan Kerja & 79 & Baik & 75 & Cukup & 74 & Cukup \\
\hline Efisiensi Tenaga & 80 & Baik & 85 & Baik & 72 & Cukup \\
\hline Efisiensi Waktu & 85 & Baik & 81 & Baik & 75 & Cukup \\
\hline \multicolumn{2}{|c|}{ Jumlah } & $\mathbf{4 9 7}$ & \multicolumn{7}{|c|}{$\mathbf{4 7 4}$} & \multicolumn{4}{|c|}{} \\
\hline Rata-Rata & $\mathbf{8 2 \%}$ & Baik & $\mathbf{7 9 \%}$ & Baik & $\mathbf{7 6 \%}$ & Cukup \\
\hline
\end{tabular}

Sumber : Data Kepegawaian YPI Amir Hamzah Medan

Berdasarkan tabel 1 diatas, dapat dilihat bahwa kondisi kinerja guru di YPI Amir Hamzah Medan Tahun 2018-2020 mengalami penurunan. Penurunan kualitas kinerja guru akan sangat menentukan pada kualitas hasil pendidikan, karena guru merupakan faktor utama yang menentukan mutu pendidikan sehingga tujuan pendidikan dapat tercapai secara maksimal.

Hasil kinerja guru tersebut, tentunya dipengaruhi oleh faktor-faktor tertentu. Berdasarkan penelitian yang dilakukan oleh Amirullah (2018) dalam Jurnalnya yang berjudul Pengaruh Komitmen Organisasi Terhadap Kinerja Guru di SMK Pasundan 1 Cimahi, mengungkapkan bahwa faktor yang mempengaruhi kinerja guru salah satunya adalah komitmen organisasi. Hal ini menunjukkan bahwa seseorang yang berkomitmen untuk organisasi akan memiliki keinginan yang kuat untuk tetap menjadi anggota organisasi tersebut, serta akan berusaha semaksimal mungkin dalam pekerjaannya. Sedangkan menurut Solichin (2013) dalam jurnalnya yang berjudul Pengaruh Kepuasan
Kerja dan Stres Kerja Terhadap Kinerja Guru Dalam Meningkatkan Mutu Akademik Lulusan Pada SMA RSBI di Kabupaten Sidoarjo menyatakan bahwa faktor yang mempengaruhi kinerja guru adalah kepuasan kerja dan stres kerja. Hal ini menunjukkan bahwa hasil kinerja guru yang semakin baik dikarenakan para guru merasa puas dengan pekerjaannya, apabila guru merasakan kepuasan terhadap pekerjaannya maka guru tersebut senantiasa bersemangat dalam mengerahkan kemampuan, pengetahuan dan kecakapannya dalam proses pembelajaran guna mencapai tujuan pendidikan, sehingga dapat memberikan hasil kinerja yang optimal. Sementara stres kerja yang dialami oleh guru mengakibatkan penurunan hasil kinerjanya karena kurang fokus terhadap tugas dan tanggung jawabnya.

Peneliti melakukan pra-survei langsung di YPI Amir Hamzah Medan untuk mengetahui faktor-faktor yang mempengaruhi hasil kinerja guru berdasarkan hasil penelitian terdahulu yaitu komitmen organisasi, kepuasan kerja dan stres kerja. Sebagimana berikut :

Tabel 2. Hasil Pra-Survei Komitmen Organisasi di YPI Amir Hamzah Medan

\begin{tabular}{|c|l|c|c|c|c|c|c|c|}
\hline \multirow{2}{*}{ No } & \multirow{7}{*}{ Dimensi } & \multicolumn{7}{c|}{ Tingkat Kesetujuan } \\
\cline { 3 - 9 } & & $\begin{array}{c}\text { SS } \\
(\mathbf{5})\end{array}$ & S (4) & $\begin{array}{c}\text { KS } \\
(\mathbf{3})\end{array}$ & $\begin{array}{c}\text { TS } \\
(\mathbf{2})\end{array}$ & $\begin{array}{c}\text { STS } \\
(\mathbf{1})\end{array}$ & $\begin{array}{c}\text { Jumlah } \\
\text { Skor }\end{array}$ & Mean \\
\hline 1 & Komitmen Afektif & 3 & 23 & 3 & 0 & 1 & 72 & 2.40 \\
\hline 2 & Komitmen Berkelanjutan & 4 & 23 & 2 & 1 & 0 & 69 & 2.30 \\
\hline 3 & Komitmen Normatif & 5 & 23 & 2 & 0 & 0 & 57 & 1.90 \\
\hline
\end{tabular}

Sumber : Hasil Olah Data Pra-Survei oleh Peneliti, 2021 
Berdasarkan tabel 2 hasil pra-survei tentang komitmen organisasi diatas, menyatakan bahwa komitmen afektif memiliki nilai mean paling tinggi yaitu sebesar 2.40 dan hal ini menunjukkan bahwa guru memiliki keterikatan secara emosional yang kuat untuk terus bekerja di SMA YPI Amir Hamzah Medan. Adapun komitmen berkelanjutan memiliki nilai mean sebesar 2.30 sedangkan komitmen normatif memiliki nilai mean sebesar 1.90. Komitmen berkelanjutan dan normatif menunjukkan adanya persepsi guru untuk tetap bekerja dan mempertahankan pekerjaannya di SMA YPI Amir Hamzah Medan sehingga para guru akan berusaha melaksanakan tugas dan tanggung jawab secara profesional dan dapat memberikan kinerja yang berkualitas.

Faktor yang mempengaruhi kinerja guru berikutnya adalah kepuasan kerja. Berikut hasil pra-survei yang diperoleh peneliti :

Tabel 3. Hasil Pra-Survei Kepuasan Kerja di YPI Amir Hamzah Medan

\begin{tabular}{|c|c|c|c|c|c|c|c|c|}
\hline \multirow{2}{*}{ No } & \multirow{8}{*}{ Dimensi } & \multicolumn{7}{|c|}{ Tingkat Kesetujuan } \\
\cline { 3 - 10 } & $\begin{array}{c}\text { SS } \\
(\mathbf{5})\end{array}$ & S (4) & $\begin{array}{c}\text { KS } \\
\mathbf{( 3 )}\end{array}$ & $\begin{array}{c}\text { TS } \\
(\mathbf{2})\end{array}$ & $\begin{array}{c}\text { STS } \\
(\mathbf{1})\end{array}$ & $\begin{array}{c}\text { Jumlah } \\
\text { Skor }\end{array}$ & Mean \\
\hline 1 & $\begin{array}{c}\text { Pekerjaan itu } \\
\text { Sendiri }\end{array}$ & 20 & 0 & 2 & 0 & 8 & 54 & 1.80 \\
\hline 2 & Gaji/Upah & 22 & 4 & 1 & 1 & 2 & 67 & 2.23 \\
\hline 3 & Jabatan & 20 & 5 & 3 & 0 & 2 & 64 & 2.13 \\
\hline 4 & Supervisi & 23 & 6 & 0 & 0 & 1 & 56 & 1.87 \\
\hline 5 & Rekan Kerja & 13 & 15 & 2 & 1 & 0 & 45 & 1.50 \\
\hline \multicolumn{7}{|c|}{ Skor Rata-Rata Komitmen Organisasi : } \\
Jumlah Skor = Nilai x Tingkat Kesetujuan \\
\hline
\end{tabular}

Sumber : Hasil Olah Data Pra-Survei oleh Peneliti, 2021

Berdasarkan tabel 3 hasil pra-survei tentang kepuasan kerja diatas, dapat dilihat bahwa kepuasan kerja dipengaruhi oleh pekerjaan itu sendiri, gaji/upah, jabatan, supervisi dan rekan kerja. Namun yang paling berpengaruh adalah gaji/upah yang diterima yaitu dengan nilai mean 2.23 dan jabatan dengan nilai mean 2.13. Hal ini menunjukkan bahwa guru SMA YPI Amir Hamzah merasa puas terhadap pekerjaannya

Tabel 4. Hasil Pra-Survei Stres Kerja di YPI Amir Hamzah Medan

\begin{tabular}{|c|l|c|c|c|c|c|c|c|}
\hline \multirow{2}{*}{ No Tabel 4. Hasil Pra-Survei Stres Kerja di YPI Amir Hamzah Medan } \\
\cline { 3 - 10 } & \multicolumn{1}{|c|}{ Dimensi } & \multicolumn{7}{c|}{ Tingkat Kesetujuan } \\
\cline { 2 - 9 } & $\begin{array}{c}\text { SS } \\
(\mathbf{5})\end{array}$ & S (4) & $\begin{array}{c}\text { KS } \\
(\mathbf{3})\end{array}$ & $\begin{array}{c}\text { TS } \\
(\mathbf{2})\end{array}$ & $\begin{array}{c}\text { STS } \\
(\mathbf{1})\end{array}$ & $\begin{array}{c}\text { Jumlah } \\
\text { Skor }\end{array}$ & Mean \\
\hline 1 & $\begin{array}{l}\text { Stres } \\
\text { Lingkungan }\end{array}$ & 15 & 10 & 1 & 1 & 3 & 72 & 2.40 \\
\hline 2 & Stres Organisasi & 11 & 15 & 2 & 2 & 0 & 81 & 2.70 \\
\hline 3 & Stres Individu & 11 & 8 & 6 & 1 & 4 & 71 & 2.37 \\
\hline
\end{tabular}

Sumber : Hasil Olah Data Pra-Survei oleh Peneliti, 2021 stres kerja diatas, dapat dilihat bahwa stres yang paling banyak dialami oleh para guru SMA YPI Amir Hamzah Medan adalah stres yang berasal dari organisasi itu sendiri, dibuktikan dengan ketika mendapatkan gaji/upah sesuai yang diharapkan serta merasa puas bekerja dengan posisi atau jabatannya. Dengan demikian, kepuasan kerja akan mendukung terciptanya kinerja yang maksimal.

Berikut ini hasil pra-survei tentang stres kerja sebagai faktor yang mempengaruhi kinerja guru adalah :
Berdasarkan tabel 4 hasil pra-survei tentang perolehan nilai mean 2.70. Sedangkan stres yang berasal dari lingkungan dan stres yang berasal dari individu tidak berbeda jauh yaitu memiliki nilai mean sebesar 2.40 dan 2.37. Hal ini menunjukkan bahwa stres kerja dapat 
mempengaruhi kualitas kinerja dikarenakan menurunnya semangat dalam melaksanakan tugas dan tanggung jawab.

\subsection{Rumusan Masalah}

Rumusan masalah pada penelitian ini ditinjau dari identifikasi dan batasan masalaha adalah sebagai berikut :

1) Apakah komitmen organisasi berpengaruh terhadap kinerja guru di Sekolah Menengah Atas YPI Amir Hamzah Medan?

2) Apakah kepuasan kerja berpengaruh terhadap kinerja guru di Sekolah Menengah Atas YPI Amir Hamzah Medan?

3) Apakah stres kerja berpengaruh terhadap kinerja guru di Sekolah Menengah Atas YPI Amir Hamzah Medan?

4) Apakah komitmen organisasi, kepuasan kerja dan stres kerja berpengaruh terhadap kinerja guru di Sekolah Menengah Atas YPI Amir Hamzah Medan?

\subsection{Batasan Masalah}

Berdasarkan latar belakang dan identifikasi masalah yang telah diuraikan, adapun batasan masalah penelitian ini adalah fokus pada 3 variabel independen dan 1 variabel dependen, yaitu komitmen organisasi sebagai X1, kepuasan kerja sebagai $\mathrm{X} 2$, stres kerja sebagai $\mathrm{X} 3$ dan kinerja guru sebagai $\mathrm{Y}$.

\subsection{Hipotesis}

Hipotesis penelitian adalah suatu jawaban intentif (sementara) terhadap masalah yang ditemukan. Dikatakan sementara karena jawaban yang diberikan baru berdasarkan pada teori dan hasil penelitian yang relevan dan belum didasarkan pada fakta-fakta yang empiris yang diperoleh melalui pengumpulan data. Berdasarkan kerangka konseptual diatas maka hipotesis penelitian adalah :

1. Secara Simultan

Terdapat pengaruh komitmen organisasi, kepuasan kerja dan stres kerja terhadap kinerja guru di Sekolah Menengah Atas YPI Amir Hamzah Medan.

2. Secara Parsial

a. Terdapat pengaruh komitmen organisasi terhadap kinerja guru di Sekolah Menengah Atas YPI Amir Hamzah Medan.

b. Terdapat pengaruh kepuasan kerja terhadap kinerja guru di Sekolah Menengah Atas YPI Amir Hamzah Medan.

c. Terdapat pengaruh stres kerja terhadap kinerja guru di Sekolah Menengah Atas YPI Amir Hamzah Medan.

Untuk lebih jelasnya pengujian hipotesis secara parsial dapat dikemukan pada uraian tabel berikut :

\section{Tabel 5. Hipotesi Penelitian}

\begin{tabular}{|l|l|}
\hline $\mathrm{H}_{0}$ & Terdapat pengaruh komitmen organisasi terhadap kinerja guru \\
$\mathrm{H}_{1}$ & Tidak terdapat pengaruh komitmen organisasi terhadap kinerja guru \\
\hline $\mathrm{H}_{0}$ & Terdapat pengaruh kepuasan kerja terhadap kinerja guru \\
$\mathrm{H}_{2}$ & Tidak terdapat pengaruh kepuasan kerja terhadap kinerja guru \\
\hline $\mathrm{H}_{0}$ & Terdapat pengaruh stres kerja kinerja guru \\
$\mathrm{H}_{3}$ & Tidak terdapat pengaruh stres kerja terhadap kinerja guru \\
\hline
\end{tabular}

\subsection{Tujuan Penelitian}

Suatu penelitian dilakukan memiliki tujuan tertentu, berdasarkan rumusan malah diatas, maka dapat diuraikan tujuan penelitian ini adalah untuk :

1) Mengetahui pengaruh komitmen organisasi terhadap kinerja guru di Sekolah Menengah Atas YPI Amir Hamzah Medan.

2) Mengetahui pengaruh kepuasan kerja terhadap kinerja guru di Sekolah Menengah Atas YPI Amir Hamzah Medan.

3) Mengetahui pengaruh stres kerja terhadap kinerja guru di Sekolah Menengah Atas YPI Amir Hamzah Medan.

4) Mengetahui pengaruh komitmen organisasi, kepuasan kerja dan stres kerja terhadap kinerja guru di Sekolah Menengah Atas YPI Amir Hamzah Medan.

\section{Metode Penelitian \\ 2.1. Populasi}

Merupakan wilayah generalisasi yang terdiri atas objek/subjek yang mempunyai kualitas dan karakter tertentu yang ditetapkan oleh peneliti untuk dipelajari dan kemudian ditarik kesimpulan. Berdasarkan pengertian populasi diatas, maka yang akan dijadikan populasi dalam penelitian ini adalah seluruh guru di Sekolah Menengah Atas (SMA) Amir Hamzah Medan yang berjumlah 48 Orang. 


\subsection{Sampel}

Sampel adalah bagian dari jumlah dan karakteristik yang dimiliki oleh populasi yang dianggap dapat mewakili. Agar dapat menggambarkan secara tepat variabel yang diteliti maka peneliti mengambil semua populasi sebagai sampelnya. Oleh karena itu teknik penarikan sampel yang menggunakan metode Sampling Jenuh. Metode sampling jenuh adalah metode lain dari sensus merupakan teknik penentuan sampel bila semua anggota populasi digunakan sebagai sampel. Berdasarkan teknik pengambilan sampel tersebut diperoleh jumlah sebanyak 38 sampel penelitian.

\subsection{Uji Normalitas}

Uji normalitas bertujuan untuk mengetahui apakah nilai residual berdistribusi normal atau tidak. Model regresi yang baik adalah memiliki nilai residual yang berdistribusi normal. Dalam penelitian ini, menggunakan uji normalitas dengan analisis Kolmogrov-Simirnov. Dimana uji Kolmogrov-Smirnov merupakan bagian dari uji asumsi klasik. Adapun dasar pengambilan keputusannya adalah:

1) Jika nilai signifikansi $>0,05$ nilai residual berdistribusi normal

2) Jika nilai signifikansi $<0,05$ nilai tidak berdistribusi normal.

Tabel 6, Uji Normalitas Kolmogrov-Smirnov

\begin{tabular}{|c|c|c|}
\hline \multicolumn{3}{|c|}{ One-Sample Kolmogorov-Smirnov Test } \\
\hline & & $\begin{array}{c}\text { Unstandardized } \\
\text { Residual }\end{array}$ \\
\hline \multicolumn{2}{|l|}{$\mathrm{N}$} & 38 \\
\hline \multirow{2}{*}{$\begin{array}{l}\text { Normal } \\
\text { Parameters }\end{array}$} & Mean & ,0000000 \\
\hline & Std. Deviation & , 48231885 \\
\hline \multirow{3}{*}{$\begin{array}{l}\text { Most Extreme } \\
\text { Differences }\end{array}$} & Absolute & , 104 \\
\hline & Positive & ,079 \\
\hline & Negative &,- 104 \\
\hline \multicolumn{2}{|l|}{ Test Statistic } & ,104 \\
\hline \multicolumn{2}{|c|}{ Asymp. Sig. (2-tailed) } & $200^{\mathrm{c}, \mathrm{d}}$ \\
\hline \multicolumn{3}{|c|}{ a. Test distribution is Normal. } \\
\hline \multicolumn{3}{|c|}{ b. Calculated from data. } \\
\hline \multicolumn{3}{|c|}{ c. Lilliefors Significance Correction. } \\
\hline \multicolumn{3}{|c|}{ d. This is a lower bound of the true significance. } \\
\hline
\end{tabular}

Berdasarkan tabel 6 diatas hasil uji Normalitas diketahui bahwa nilai signifikan (Asymp.Sig. 2 tailed) adalah kisaran 0,200. Yaitu nilai signifikansi 0,200>0,05 maka dapat disimpulkan bahwa nilai residual berdistribusi normal. Dengan demikian dapat disimpulkan uji normalitas berhasil.

\subsection{Uji Multikolinearitas}

Uji Multikolinearitas bertujuan untuk mengetahui apakah terjadi interkorelasi antara variabel independen. Salah satu cara yang paling akurat untuk mendeteksi ada atau tidaknya gejala Multikolinearitas adalah dengan menggunakan metode Tolerance dan VIF (Variance Inflation Factor). Adapun dasar pengambilan keputusannya adalah :

1) Melihat nilai Tolerance : Jika Nilai Tolerance (T) lebih besar > dari 0,10 maka artinya tidak terjadi Multikolinearitas

2) Melihat nilai VIF : Jika nilai VIF lebih kecil $<$ dari 10,00 maka artinya tidak terjadi Multikolinearitas.

Tabel 7. Uji Multikolinearitas

\begin{tabular}{|l|r|r|}
\hline \multicolumn{3}{|c|}{ Coeficients $^{\mathbf{a}}$} \\
\hline \multirow{2}{*}{ Model } & \multicolumn{2}{|c|}{ Collinearity Statistics } \\
\cline { 2 - 3 } & Tolerance & \multicolumn{1}{c|}{ VIF } \\
\hline (Constant) & & \\
Komitmen Organisasi (X1) &, 990 & 1,010 \\
Kepuasan Kerja (X2) &, 697 & 1,434 \\
Stres Kerja (X3) &, 697 & 1,435 \\
\hline a. Dependent Variabel : Kinerja Guru $(Y)$ & \\
\hline
\end{tabular}


Berdasarkan tabel 7 diatas terlihat bahwa nilai Tolerance komitmen kerja sebesar 0,990 $(0,990>0,10)$, nilai Tolerance kepuasan kerja sebesar $0,697(0,697>0,10)$ dan nilai Tolerance stres kerja sebesar 0,697 (0,697 > $0,10)$. Sedangkan untuk nilai VIF komitmen kerja sebesar $1,010(10,00<0,10)$, nilai VIF kepuasan kerja sebesar 1,434 $(1,434<10,00)$ dan nilai VIF stres kerja sebesar 1,435 (1,435 < 10,00). Kesimpulan dari nilai Tolerance menunjukkan > 0,10 dan nilai VIF $<10,00$ berarti menunjukkan tidak terdapat Multikolinearitas.

\subsection{Uji Heteroskedastisitas}

Uji Heteroskedastisitas bertujuan menguji apakah dalam model regresi terjadi ketidaksamaan variance dari residual satu pengamatan ke pengamatan yang lain. Untuk mendeteksi ada tidaknya Heteroskedastisitas yaitu dengan melihat pada gambar analisis grafik Scatterplot dan uji Glejser. Berikut ini adalah uraian dari hasil uji Heteroskedastisitas yaitu :

\section{1) Analisis Grafik Scatterplot}

Berikut ini adalah dasar pengambilan keputusan untuk analisis grafik Scatterplot :

a) Titik-titik data terlihat menyebar diatas dan dibawah atau disekitar angka 0.

b) Penyebaran titik-titik data tidak boleh membentuk pola bergelombang melebar kemudian menyempit dan melebar kembali atau penyebaran titik-titik tidak berpola.
Adapun hasil uji Heteroskedastisitas menggunakan grafik Scatterplot seperti terlihat pada gambar dibawah ini :

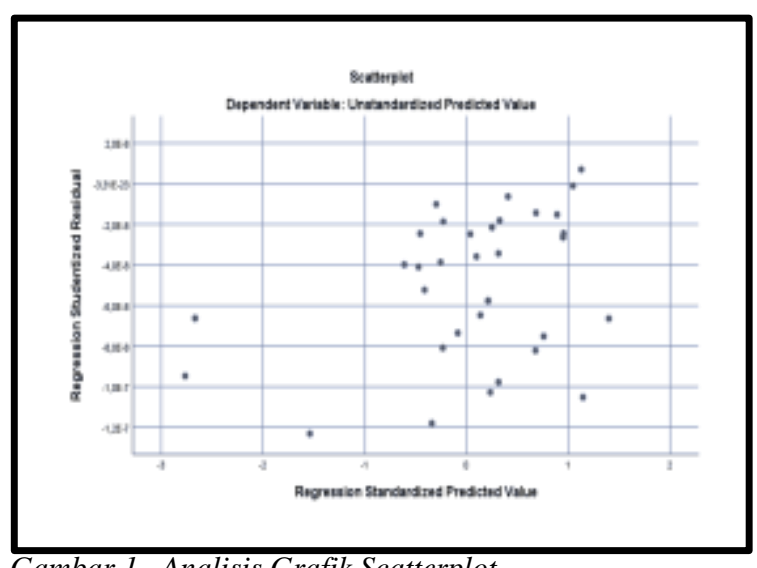

Gambar 1. Analisis Grafik Scatterplot

Berdasarkan gambar 1 diatas terlihat bahwa pada grafik scatterplot diatas titik-titik menyebar secara acak, baik di atas maupun di bawah angka 0 pada sumbu Y. Hal ini dapat disimpulkan bahwa tidak terjadi heteroskedastisitas pada model regresi.

\section{2) Uji Glejser}

Uji Heteroskedastisitas kedua adalah dengan uji Glejser, dimana uji Glejser digunakan untuk mengatasi keraguan terhadap hasil uji grafik Scatterplot. Dasar pengambilan keputusannya adalah jika sig > 0,05 maka tidak terjadi heteroskedastisitas dan jika sig < 0,05 maka terjadi heteroskedastisitas. Adapun hasil uji Heteroskedastisitas menggunakan uji Glejser dapat dilihat pada tabel berikut :

Tabel 8. Uji Glejser

\begin{tabular}{|l|r|r|r|r|r|}
\hline \multicolumn{7}{|c|}{ Coefficients $^{\mathbf{a}}$} \\
\hline \multirow{2}{*}{ Model } & \multicolumn{2}{|c|}{$\begin{array}{c}\text { Unstandardized } \\
\text { Coefficients }\end{array}$} & $\begin{array}{c}\text { Standardized } \\
\text { Coefficients }\end{array}$ & \multirow{2}{*}{ S } & \\
\cline { 2 - 5 } & \multicolumn{1}{|c|}{$\mathrm{B}$} & Std. Error & Beta & & \\
\hline (Constant) & $-2,550$ &, 633 & & 4,031 &, 000 \\
\hline Komitmen Kerja (X1) &, 033 &, 005 &, 000 & 6,392 &, 681 \\
\hline Kepuasan Kerja (X2) &, 037 &, 014 &, 011 & 2,696 &, 542 \\
\hline Stres Kerja (X3) &,- 001 &, 017 &,- 005 &,- 037 &, 971 \\
\hline a. Dependent Variable: Kinerja Guru \\
Sumber : Data diolah dengan menggunakan SPSS
\end{tabular}

Berdasarkan tabel 8 diatas terlihat bahwa nilai signifikansi komitmen kerja sebesar 0,681 , kepuasan kerja sebesar 0,542 dan stres kerja sebesar 0,971. Maka nilai signifikansi tersebut adalah diatas tingkat kepercayaan 5\% ( > 0,05) yang berarti bahwa model regresi tidak mengandung adanya Heteroskedastisitas.

\subsection{Uji Autokorelasi}

Uji Autokorelasi bertujuan menguji apakah dalam model regresi linier ada korelasi antara kesalahan pengganggu pada periode $t$ dengan kesalahan pengganggu pada periode $\mathrm{t}-1$ (sebelumnya). Jika terjadi korelasi, maka dinamakan ada problem autokorelasi. Untuk mendeteksi ada atau tidaknya autokorelasi 
dengan melihat nilai. D-W (Durbin Watson). Dasar pengambilan keputusan nilai D-W (Durbin Watson) adalah :

1) Jika d < dari dL atau > dari $(4-d L)$ maka terdapat autokorelasi.

2) Jika d terletak diantara dU dan 4-dU maka tidak terdapat autokorelasi.
3) Jika d terletak antara dL dan dU atau diantara 4 - dU dan 4 - dL maka tidak menghasilkan kesimpulan yang pasti.

Hasil uji Autokorelasi dapat diperhatikan pada tabel dibawah ini dengan melihat pada nilai D-W (Durbin Watson) :

Tabel 9. Uji Autokorelasi

\begin{tabular}{|c|c|c|c|c|c|}
\hline \multicolumn{6}{|c|}{ Model Summary ${ }^{b}$} \\
\hline Model & $\mathrm{R}$ & $\begin{array}{c}\mathrm{R} \\
\text { Square }\end{array}$ & $\begin{array}{c}\text { Adjusted R } \\
\text { Square }\end{array}$ & $\begin{array}{l}\text { Std. Error of } \\
\text { the Estimate }\end{array}$ & $\begin{array}{l}\text { Durbin- } \\
\text { Watson }\end{array}$ \\
\hline 1 &, $748^{\mathrm{a}}$ &, 559 &, 520 & 482 & 2,574 \\
\hline \multicolumn{6}{|c|}{ a. Predictors: (Constant), Komitmen Organisasi_X1, Kepuasan Kerja_X2, Stres Kerja_X3 } \\
\hline b. Depen & ariable & nerja Guru_ & & & \\
\hline
\end{tabular}

Cara mendeteksi ada atau tidaknya gejala Autokorelasi maka perlu dibandingkan antara nilai Durbin Watson dengan dL dan dU. Nilai $\mathrm{dL}$ dan $\mathrm{dU}$ diperoleh berdasarkan perhitungan yang terdapat pada tabel D-W (Durbin Watson), adapun hasil perhitungan nilai $\mathrm{dL}$ dan $\mathrm{dU}$ sebagai berikut ini :

\begin{tabular}{|l|c|c|c|c|}
\hline Nilai d & Nilai DI & Nilai dU & Nilai 4 - dL & Nilai 4 - dU \\
\hline 2.574 & 1.6563 & 1.264 & 2.343 & 2.736 \\
\hline
\end{tabular}

Berdasarkan tabel 9 uji Autokorelasi diatas, adapun nilai D-W (Durbin Watson) adalah sebesar 2.263, maka hasil dari uji Autokorelasi memberikan kesimpulan bahwa nilai d terletak diantara dU dan 4-dU, dimana nilai batas atas (dU) yaitu 1.264 lebih kecil < dari nilai Durbin Watson (d) yaitu 2.574 dan lebih kecil < dari nilai 4 - dU yaitu 2.736. Dengan demikian disimpulkan bahwa pada uji Autokorelasi tidak

\section{Analisis Regresi Linear Berganda}

Analisis regresi linear berganda merupakan studi mengenai ketergantungan variabel dependen dengan beberapa variabel independen. Adapun hasil regresi linear berganda pada penelitian ini sebagaimana diuraikan pada tabel dibawah ini : terdapat gejala Autokorelasi.

Tabel 10. Analisis Regresi Linear Berganda

\begin{tabular}{|c|c|c|c|c|c|}
\hline \multicolumn{6}{|c|}{ Coefficients $^{\mathrm{a}}$} \\
\hline \multirow[t]{2}{*}{ Model } & \multicolumn{2}{|c|}{$\begin{array}{c}\text { Unstandardized } \\
\text { Coefficients }\end{array}$} & \multirow{2}{*}{$\begin{array}{c}\text { Standardized } \\
\text { Coefficients } \\
\text { Beta }\end{array}$} & \multirow[b]{2}{*}{$\mathrm{T}$} & \multirow[b]{2}{*}{ Sig. } \\
\hline & B & Std. Error & & & \\
\hline Constant & 6,822 & 1,739 & & 3,924 &, 000 \\
\hline $\mathrm{X} 1$ & ,349 & ,014 & ,408 & 3,562 & ,001 \\
\hline $\mathrm{X} 2$ &, 510 &, 038 & 504 & 3,696 & 001 \\
\hline X3 &, 141 & 046 & 240 & 3,760 & ,027 \\
\hline
\end{tabular}

Cara mengetahui hasil regresi linear $Y$ berganda dapat disusun dengan rumus persamaan dibawah ini :

$$
\begin{aligned}
& Y=a+b_{1} X_{1}+b_{2} X_{2}+b_{3} X_{3}+E \\
& Y=6,822+051 X_{1}+141 X_{2}+b_{1} b_{2} b_{3} \\
& 082 X_{3}+1,739=8,753
\end{aligned}
$$

Variabel dependen atau terikat (Kinerja Guru)

Konstanta persamaan regresi

Koefisien regresi

Variabel Independen (Komitmen Kerja)

Keterangan : 
$\mathrm{X}_{2} \quad$ : Variabel Independen (Kepuasan Kerja)

$\mathrm{X}_{3} \quad$ : Variabel Independen (Stres Kerja)

E : Error terms atau faktor pengganggu

Berdasarkan tabel 10 dan hasil perumusan pada persamaan regresi linear berganda tersebut maka dapat diinterpretasikan ketergantungan antara variabel bebas dengan variabel terikat :

1) Konstanta bernilai positif sebesar 8,753menunjukkan adanya hubungan searah antara variabel $\mathrm{X}$ dan variabel $\mathrm{Y}$, bahwa apabila variabel komitmen organisasi, kepuasan kerja dan stres kerja dianggap konstan (0) maka persentase peningkatan kinerja guru adalah sebesar 87,5\%.

2) Koefisien regresi pada variabel komitmen organisasi $\left(b_{1}\right)$ bernilai positif yaitu 0,349 hal ini berarti komitmen organisasi menunjukkan hubungan searah dengan kinerja guru dan memiliki tingkat ketergantungan sebesar 34,9\%.

3) Koefisien regresi variabel kepuasan kerja $\left(b_{2}\right)$ bernilai positif 0,510 hal ini berarti menunjukkan adanya hubungan searah antara kepuasan kerja dengan kinerja guru dan memiliki tingkat ketergantungan sebesar $51 \%$.

4) Koefisien regresi variabel stres kerja $\left(b_{3}\right)$ bernilai positif 0,141 hal ini berarti menunjukkan adanya hubungan searah antara stres kerja dengan kinerja guru dan memiliki tingkat ketergantungan sebesar $14,1 \%$.

Hasil regresi linear berganda diatas menyatakan bahwa variabel bebas yang

memberikan pengaruh paling kuat terhadap variabel terikat adalah Kepuasan Kerja. Pernyataan ini dapat dibuktikan dengan nilai koefisien regresi (B) sebesar 0,349 dibandingkan nilai koefisien regresi variabel bebas lainnya. Komitmen organisasi sebesar 0,51 sedangkan stres kerja sebesar 0,141. Dengan demikian, kepuasan kerja merupakan faktor paling berpengaruh kuat terhadap peningkatan kinerja guru, hal ini disebabkan kepuasan kerja yang dirasakan dapat mempengaruhi perilaku guru dalam melaksanakan tugas dan tanggung jawabnya dengan baik. Disamping itu komitmen organisasi juga memegang peran penting dalam konsistensi guru untuk mempertahankan pekerjaannya, sedangkan stres kerja mempengaruhi semangat guru dalam bekerja.

\subsection{Uji Hipotesis}

a. Uji T (Parsial)

Uji-T (parsial) pada dasarnya menunjukkan seberapa jauh pengaruh satu variabel penjelas/independen secara individual dalam menerangkan variasi variabel dependen yang diuji pada tingkat signifikan 0,05. Berikut adalah uraian ketentuan pengambilan Keputusan untuk uji T (Parsial) :

1) Jika nilai sig $<0,05$ atau $\mathrm{T}$ hitung $>\mathrm{T}$ tabel maka terdapat pengaruh variabel $\mathrm{X}$ terhadap variabel Y.

2) Jika nilai sig $>0,05$ atau $T$ hitung $<\mathrm{T}$ tabel maka tidak terdapat pengaruh variabel $\mathrm{X}$ terhadap variabel Y.

Berikut ini merupakan tabel yang memaparkan hasil terhadap uji $\mathrm{T}$ (parsial) yaitu sebagai berikut :

Tabel 11. Uji T (Parsial)

\begin{tabular}{|c|c|c|c|c|c|}
\hline Coefficients $^{\mathbf{a}}$ & \multicolumn{7}{|c|}{} \\
\hline Model & Unstandardized Coefficients & $\begin{array}{c}\text { Standardized } \\
\text { Coefficients }\end{array}$ & \multirow{2}{*}{ T } & \multirow{2}{*}{ Sig. } \\
\cline { 2 - 5 } & $\mathrm{B}$ & Std. Error & Beta & &, 000 \\
\hline Constant & 6,822 & 1,739 & & 3,924 &, 001 \\
\hline X1 &,- 051 &, 014 &, 408 & 3,562 &, 001 \\
\hline X2 &, 141 &, 038 &, 504 & 3,696 &, 027 \\
\hline X3 &, 082 &, 046 &, 240 & 3,760 & \\
\hline a. Dependent Variable $:$ Variabel_Y
\end{tabular}

Sumber : Data diolah dengan menggunakan SPSS

Cara mengetahui hasil uji $\mathrm{T}$ (parsial) diatas apakah mempengaruhi variabel $\mathrm{X}$ terhadap variabel $\mathrm{Y}$ maka perlu dibandingkan dengan hasil nilai $\mathrm{T}$ tabel yaitu dengan rumus :

$\mathrm{T}$ tabel $=\mathrm{t}(\mathrm{a} / 2: \mathrm{n}-\mathrm{k}-1)=\mathrm{t}(0,025: 33)=$ 2.0345
Keterangan :

a : Tingkat kepercayaan $(0,05 / 2=0,025)$

$\mathrm{N}$ : Jumlah sampel penelitian (38)

$\mathrm{K}$ : Jumlah variabel X (3) 
Berdasarkan pada tabel 11 diatas dapat disimpulkan bahwa hasil uji hipotesis melalui uji T (Parsial) dengan membandingkannya pada nilai $\mathrm{T}$ tabel adalah sebagai berikut :

1) Komitmen Organisasi

Hasil uji $\mathrm{T}$ (Parsial) menunjukkan nilai signifikan (sig) untuk pengaruh X1 terhadap $\mathrm{Y}$ adalah sebesar $0,001<0,05$ dan nilai $\mathrm{T}$ hitung sebesar $3.562>$ dari $\mathrm{T}$ tabel 2.034 sehingga dapat disimpulkan terdapat pengaruh variabel X1 terhadap variabel $Y$.

2) Kepuasan Kerja

Hasil uji $\mathrm{T}$ (Parsial) menunjukkan nilai signifikan (sig) untuk pengaruh $\mathrm{X} 2$ terhadap $\mathrm{Y}$ adalah sebesar $0,001<$ dari 0,05 dan nilai $\mathrm{T}$ hitung sebesar $3.696>$ dari $\mathrm{T}$ tabel 2.034 sehingga dapat disimpulkan terdapat pengaruh variabel $\mathrm{X} 2$ terhadap variabel $\mathrm{Y}$.

3) Stres Kerja

Hasil uji $\mathrm{T}$ (Parsial) menunjukkan nilai signifikan (sig) untuk pengaruh X3 terhadap Y adalah sebesar $0,027<$ dari 0,05 dan nilai $\mathrm{T}$ hitung sebesar $3.760>$ dari $\mathrm{T}$ tabel 2.034 sehingga dapat disimpulkan terdapat pengaruh variabel X3 terhadap variabel $\mathrm{Y}$.

\section{b. Uji S (Simultan)}

Uji statistik F (simultan) bertujuan untuk mengetahui ada atau tidaknya pengaruh secara simultan (bersama-sama) yang diberikan variabel bebas $(\mathrm{X})$ terhadap variabel terikat $(\mathrm{Y})$ yaitu untuk mengetahui apakah terdapat pengaruh komitmen kerja, kepuasan kerja dan stres kerja terhadap kinerja guru yang diuji dengan tingkat signifikansi 0,05 . Adapun dasar pengambilan keputusan uji $\mathrm{F}$ (simultan) adalah sebagai berikut :

1) Jika nilai sig $<0,05$ atau $F$ hitung $>F$ tabel maka terdapat pengaruh variabel $\mathrm{X}$ secara simultan terhadap variabel Y.

2) Jika nilai sig $>0.05$ atau $F$ hitung $<F$ tabel maka tidak terdapat pengaruh variabel $X$ secara simultan terhadap variabel $\mathrm{Y}$

Cara unutuk mengetahui ada tidaknya pengaruh variabel bebas $(\mathrm{X})$ terhadap variabel terikat (Y) menggunakan uji F (Simultan) maka perlu diketahui hasil $\mathrm{F}$ tabel, yaitu dengan rumus :

$\mathrm{F}$ tabel $=\mathrm{F}(\mathrm{k}: \mathrm{n}-\mathrm{k})=\mathrm{F}(3: 35)=2,85$

Keterangan :

a : Tingkat kepercayaan $(0,05)$

$\mathrm{N}$ : Jumlah sampel penelitian (38)

$\mathrm{K}$ : Jumlah variabel $\mathrm{X}(3)$

Berikut ini merupakan tabel yang memaparkan hasil terhadap uji $\mathrm{F}$ (simultan) yaitu sebagai berikut :

Tabel 12. Uji F (Simultan)

\begin{tabular}{|c|c|c|c|c|c|}
\hline \multicolumn{6}{|l|}{ ANOVA $^{\mathrm{a}}$} \\
\hline Model & $\begin{array}{l}\text { Sum of } \\
\text { Squares }\end{array}$ & Df & $\begin{array}{l}\text { Mean } \\
\text { Square }\end{array}$ & $\mathrm{F}$ & Sig. \\
\hline Regression & 10,006 & 3 & 3,335 & 14,375 &, $000^{\mathrm{b}}$ \\
\hline Residual & 7,889 & 34 & .232 & & \\
\hline Total & 17,895 & 37 & & & \\
\hline \multicolumn{6}{|c|}{ a. Dependent Variable: $:$ Kinerja Guru_Y $Y$} \\
\hline
\end{tabular}

Berdasarkan tabel 12 diatas dapat diketahui bahwa nilai signifikansi (sig) untuk pengaruh variabel bebas $\mathrm{X} 1, \mathrm{X} 2$ dan $\mathrm{X} 3$ terhadap variabel terikat $\mathrm{Y}$ sebesar $0,000<0,05$ dan nilai $\mathrm{F}$ hitung adalah $14.375>\mathrm{F}$ tabel 2.85 sehingga dapat disimpulkan bahwa terdapat pengaruh komitmen organisasi, kepuasan kerja dan stres kerja secara simultan terhadap kinerja guru.

\section{c. Koefisien Determinasi $\left(\mathbf{R}^{2}\right)$}

Koefisien determinasi $\left(\mathrm{R}^{2}\right)$ pada intinya mengukur seberapa jauh kemampuan model dalam menerangkan variasi variabel independen. Nilai koefisien determinasi adalah antara nol dan satu. Nilai $\mathrm{R}^{2}$ yang kecil berarti kemampuan variabel-variabel independen dalam menjelaskan variasi variabel dependen amat terbatas. Nilai yang mendekati satu berarti variabel-variabel independen memberikan hampir semua informasi yang dibutuhkan untuk memprediksi variasi variabel dependen. Berikut hasil uji koefisien determinasi : 
Tabel 13. Koefisien Determinasi $\left(\mathrm{R}^{2}\right)$

\begin{tabular}{|c|c|c|c|c|c|}
\hline \multicolumn{6}{|c|}{ Model Summary ${ }^{b}$} \\
\hline Model & $\mathrm{R}$ & $\begin{array}{c}\mathrm{R} \\
\text { Square }\end{array}$ & $\begin{array}{l}\text { Adjusted } \\
\text { R Square }\end{array}$ & $\begin{array}{l}\text { Std. Error of } \\
\text { the Estimate }\end{array}$ & $\begin{array}{l}\text { Durbin- } \\
\text { Watson }\end{array}$ \\
\hline 1 &, $748^{\mathrm{a}}$ & 559 &, 520 & 482 &, 574 \\
\hline \multicolumn{6}{|c|}{ a. Predictors : (Constant), Komitmen Kerja_X1, Kepuasan Kerja_X2,Stres Kerja_X3 } \\
\hline \multicolumn{6}{|c|}{ b. Dependent Variable $:$ Kinerja Guru_Y } \\
\hline
\end{tabular}

Berdasarkan tabel 13 diatas dapat disimpulkan nilai $\mathrm{R}$ Square sebesar sebesar 0,559 hal ini mengandung arti bahwa pengaruh variabel $\mathrm{X}$ secara simultan terhadap variabel $\mathrm{Y}$ adalah sebesar 55,9\%. Sehingga dapat dikatakan pengaruh komitmen organisasi, kepuasan kerja dan stres kerja terhadap kinerja guru, dilihat dari koefisien determinasinya $\left(\mathrm{R}^{2}\right)$ adalah tergolong sedang. Adapun sisanya yaitu sebesar 44,1\% dipengaruhi oleh variabelvariabel lainnya yang tidak dimasukkan kedalam penelitian ini.

\section{Evaluasi Data Penelitian}

Berikut ini merupakan evaluasi dan penyesuaian antara hasil penelitian dengan penelitian terdahulu berdasarkan hipotesis yang diteliti :

\section{1) Pengaruh Komitmen Organisasi Terhadap Kinerja Guru}

Hasil uji $\mathrm{T}$ (Parsial) menunjukkan nilai signifikan (sig) untuk pengaruh X1 terhadap Y adalah sebesar $0,001<0,05$ dan nilai $\mathrm{T}$ hitung sebesar $3.562>$ dari $\mathrm{T}$ tabel 2.034 sehingga dapat disimpulkan komitmen organisasi secara parsial berpengaruh signifikan terhadap kinerja guru. Hasil penelitian ini mendukung hasil penelitian yang dilakukan oleh Suriani (2020) yang menunjukkan hasil pengujian parsial (Uji T) antara variabel komitmen organisasi terhadap kinerja guru menunjukkan nilai signifikan (sig) sebesar 0.04 nilai ini lebih kecil dari nilai alphanya yang sebesar 0.05 dan $\mathrm{T}$ hitung lebih besar dari $\mathrm{T}$ tabel $(3,699>2,045$. Hasil penelitian terdahulu lainnya yang mendukung hasil penelitian ini yaitu penelitian yang dilakukan oleh Liana (2018) menyatakan bahwa nilai signifikan (sig) sebesar 0,028 yaitu lebih kecil dari 0,05. Dengan demikian dapat dinyatakan bahwa hipotesis penelitian untuk pengujian $\mathrm{H}_{0}$ ditolak sedangkan $\mathrm{H}_{1}$ diterima, yaitu Komitmen Organisasi secara parsial berpengaruh positif dan signifikan terhadap Kinerja Guru. Guru yang memiliki komitmen terhadap organisasinya cenderung akan memiliki keterikatan emosional yang kuat terhadap organisasi tempat kerjanya, keinginan kuat untuk memelihara hubungan yang kuat dengan organisasi serta memiliki kesiapan memberikan yang terbaik bagi SMA YPI Amir Hamzah Medan.

\section{2) Pengaruh Kepuasan Kerja Terhadap Kinerja Guru}

Hasil uji $\mathrm{T}$ (Parsial) menunjukkan nilai signifikan (sig) untuk pengaruh $\mathrm{X} 2$ terhadap $\mathrm{Y}$ adalah sebesar $0,001<$ dari 0,05 dan nilai $\mathrm{T}$ hitung sebesar $3.696>$ dari $\mathrm{T}$ tabel 2.034 sehingga dapat disimpulkan terdapat pengaruh kepuasan kerja terhadap kinerja guru. Hasil penelitian ini mendukung hasil penelitian yang dilakukan oleh Nahrul Hayat (2018) menyatakan bahwa kepuasan kerja berpengaruh terhadap kinerja guru, yaitu dengan membuktikan nilai signifikan (sig) adalah 0,000 $<0,05$ dan nilai $\mathrm{T}$ hitung lebih besar dari $\mathrm{T}$ tabel $(4,254>1,674)$. Hasil penelitian ini juga didukung oleh penelitian yang dilakukan oleh Lutviani (2014) dengan menunjukkan hasil nilai signifikan (sig) sebesar 0,018 yang berarti $(0,018<0,05)$. Dengan demikian dapat dinyatakan bahwa hipotesis penelitian untuk pengujian $\mathrm{H}_{0}$ ditolak sedangkan $\mathrm{H}_{2}$ diterima, yaitu Kepuasan Kerja secara parsial berpengaruh positif dan signifikan terhadap Kinerja Guru. Adapun indikator-indikator yang mempengaruhi kepuasan kerja guru yaitu pekerjaan itu sendiri, gaji/upah yang diterima, jabatan yang sedang ditempati, pemberian supervisi serta sesama rekan kerja. Hal inilah yang membuat guru SMA YPI Amir Hamzah Medan merasa puas dengan pekerjaannya sehingga selalu berusaha memberikan kinerja yang baik.

\section{3) Pengaruh Stres Kerja Terhadap Kinerja Guru}

Hasil uji $\mathrm{T}$ (Parsial) menunjukkan nilai signifikan (sig) untuk pengaruh $\mathrm{X} 3$ terhadap $\mathrm{Y}$ adalah sebesar $0,027<$ dari 0,05 dan nilai $\mathrm{T}$ hitung sebesar $3.760>$ dari $\mathrm{T}$ tabel 2.034 sehingga dapat disimpulkan terdapat pengaruh 
stres kerja terhadap kinerja guru. Hasil penelitian ini mendukung hasil penelitian yang dilakukan oleh Zainul (2016) menyatakan bahwa stres kerja berpengaruh terhadap kinerja guru, hal ini dibuktikan dengan hasil uji $\mathrm{T}$ pada variabel X1 yaitu Stres diperoleh nilai T hitung -2, 183 dengan signifikansi 0,047. Dengan menggunakan batas signifikansi 5\% atau 0,05 diperoleh $\mathrm{T}$ tabel sebesar 2,040. Ini berarti $\mathrm{t}$ hitung $(2,183)>\mathrm{t}$ tabel $(2,040)$. Penelitian Lutviani (2014) juga menunjukkan hasil serupa dengan penelitian ini yaitu nilai signifikan (sig) untuk variabel stres kerja adalah sebesar 0,035 $<0,05$. Dari hasil uji $\mathrm{T}$ tersebut dapat dinyatakan bahwa hipotesis untuk $\mathrm{H}_{0}$ ditolak dan $\mathrm{H}_{3}$ ditrima. Maka dapat disimpulkan secara parsial terdapat pengaruh stres yang signifikan terhadap kinerja guru. Oleh sebab itu, Stres kerja yang tinggi akan mengakibatkan menurunnya kinerja, sebaliknya rendahnya tingkat stres kerja bahkan tergolong tidak ada ada stres kerja dapat meningkatkan kualitas kinerja.

\section{4) Pengaruh Komitmen Organisasi, Kepuasan Kerja dan Stres Kerja Terhadap Kinerja Guru}

Nilai signifikansi (sig) untuk pengaruh variabel bebas $\mathrm{X} 1, \mathrm{X} 2$ dan $\mathrm{X} 3$ terhadap variabel terikat $\mathrm{Y}$ sebesar $0,000<0,05$ dan nilai $\mathrm{F}$ hitung adalah $14.375>\mathrm{F}$ tabel 2.85 sehingga dapat disimpulkan bahwa terdapat pengaruh komitmen organisasi, kepuasan kerja dan stres kerja secara simultan terhadap kinerja guru. Hasil penelitian ini didukung oleh hasil penelitian terdahulu yang dilakukan oleh Rismawati (2019) menunjukkan hasil bahwa nilai signifikan (sig) untuk pengaruh variabel bebas $\mathrm{X} 1, \mathrm{X} 2$ dan $\mathrm{X} 3$ terhadap variabel terikat (Y) sebesar $0,000<0,05$. Adapun penelitian terdahulu lainnya yang serupa dengan hasil penelitian ini yaitu penelitian yang dilakukan oleh Zainul (2018) menunjukkan hasil nilai signifikansi (sig) untuk variabel $\mathrm{X}$ terhadap $\mathrm{Y}$ secara simultan adalah sebesar $0,000<0,05$ dan nilai $\mathrm{T}$ hitung lebih besar dari $\mathrm{T}$ tabel $(32,237>$ 3,17). Berdasarkan hasil penelitian dan penelitian terdahulu dapat disimpulkan bahwa Komitmen Organisasi, Kepuasan Kerja dan Stres Kerja secara bersama-sama (simultan) berpengaruh terhadap kinerja guru.

Adapun variabel bebas yang memberikan pengaruh paling kuat terhadap variabel terikat adalah kepuasan kerja. Pernyataan ini dapat dibuktikan dengan nilai koefisien regresi (B) sebesar 0,510 dibandingkan nilai koefisien regresi variabel bebas lainnya. Komitmen organisasi sebesar 0,349 dan stres kerja sebesar 0,144. Karena itu kepuasan kerja menjadi variabel yang berpengaruh paling kuat (signifikan) terhadap kualitas kinerja guru.

Tingkat hubungan antara pengaruh variabel $\mathrm{X}$ terhadap variabel $\mathrm{Y}$ berdasarkan nilai $\mathrm{R}$ Square adalah sebesar 0,559 hal ini mengandung arti bahwa pengaruh variabel $X$ secara simultan terhadap variabel $\mathrm{Y}$ adalah sebesar 55,9\%. Sehingga dapat dikatakan pengaruh komitmen organisasi, kepuasan kerja dan stres kerja terhadap kinerja guru, dilihat dari koefisien determinasinya $\left(\mathrm{R}^{2}\right)$ adalah tergolong sedang, karena nilai 0,559 berada pada interpretas koefisien determinasi $\left(\mathrm{R}^{2}\right)$ yaitu $0,40-0,599$ yang berarti tingkat hubungannya adalah sedang. Adapun sisanya yaitu sebesar $44,1 \%$ dipengaruhi oleh variabelvariabel lainnya yang tidak dimasukkan kedalam penelitian ini. Maka dapat dikatakan pengaruh komitmen organisasi, kepuasan kerja dan stres kerja terhadap kinerja guru berpotensi sedang dikarenakan interval koefisiennya berada pada kisaran 0,40 - 0,599. Secara singkat, analisis terhadap evaluasi hasil penelitian menyatakan bahwa komitmen organisasi, kepuasan kerja dan stres kerja berpengaruh signifikan baik secara parsial maupun simultan terhadap kinerja guru di Sekolah Menengah Atas YPI Amir Hamzah Medan.

\section{Kesimpulan}

Analisis hasil penelitian dan pembahasan yang telah dipaparkan pada bab sebelumnya, maka dapat diambil kesimpulan sebagai berikut

1) Komitmen Organisasi berpengaruh terhadap Kinerja Guru di Sekolah Menengah Atas YPI Amir Hamzah Medan.

2) Kepuasan Kerja berpengaruh terhadap Kinerja Guru di Sekolah Menengah Atas YPI Amir Hamzah Medan.

3) Stres Kerja berpengaruh terhadap Kinerja Guru di Sekolah Menengah Atas YPI Amir Hamzah Medan.

4) Komitmen Organisasi, kepuasan kerja dan stres berpengaruh terhadap Kinerja Guru di Sekolah Menengah Atas YPI Amir Hamzah Medan. 
DAFTAR PUSTAKA

Amirullah, Abdul Khalik. 2018. Pengaruh Komitmen Organisasi dan Motivasi Kerja Terhadap Kinerja Guru di SMK Pasundan 1 Cimahi. Jurnal Pendidikan Manajemen. Vol. 3 No. 2

Allen, N.J dan J.P Meyer. 1991. The Measurement and Antecedents Of Affectif, Continuance and Normative Commitmen to The Organizational. Juornal Of Occupational Psychology.

Arikunto, S. 2013. Prosedur Penelitian : Suatu Pendekatan Praktik. Jakarta: Rineka Cipta.

Dessler, Gary. 2016. Manajemen SumberDaya Manusia, Jilid 1 Edisi 10, Alih Bahasa : Paramita Rahay. Jakarta : Indeks.

Fred, Luthans. 2006. Perilaku Organisasi, Alih Bahasa V. A Yuwono, Yogyakarta : CV. Andi Offset

Greenberg, J dan Baron RA. 2003. Behavior In Organizational Understanding and Managing The Human Side Of Work. New Jersey : Practic Hall International.

Hani Handoko. 2002. Manajemen Personalia dan Sumberdaya Manusia. Yogyakarta : BPFE.

Hasibuan, Malayu S.P. 2004. Manajemen Sumber Daya Manusia. Cetakan ke Tujuh, edisi revisi. Jakarta : PT. Bumi Aksara.

Hayat, Nahrul. 2018. Pengaruh Kepuasan Kerja dan Stres Kerja Terhadap Kinerja Guru di MTs Negeri 1 Bandar Lampung. Jurnal Manajemen Pendidikan, Vol. 3 No.2

Hidayat, Zainul. 2016. Pengaruh Stres Kerja dan Kelelahan Kerja Terhadap Kinerja Guru SMPN 2 Sukodono di Kabupaten Lumajang. Jurnal Penelitian Ilmu Ekonomi WIGA, Vol. 6 No. 1, Hal. 36-44

Kusmianto. 20017. Panduan Penilaian Kinerja Guru Oleh Pengawas. Jakarta : PT. Erlangga. 2011.

Kusmaryani, Rosita Endang. 2009. Komitmen Terhadap Pekerjaan dan Kinerja Guru Pembimbing diKabupaten Bantul. Jurnal Penelitian Dan Pengembangan Pemerintah Provinsi DIY. Vol. 1. No. 1

Kusdi. 2011. Budaya Organisasi-Teori dan Praktik. Jakarta : Salemba Empat

Kreitner, Robert. 2011. Perilaku Organisasi. Jakarta : Salemba Empat.

Lutviani Rahayu. Pengaruh Kepuasan Kerja Terhadap Kinerja Guru di SMP Negeri 5 Magelang. Jurnal FE Unnes. ISSN 22526544. Diakses pada http//journal.unnes.ac.id/sju/index.php/eeaj
Mangkunegara, Anwar Prabu. 2017. Manajemen Sumber Daya Manusia Perusahaan. Bandung : Remaja Rosdakarya

Mangkuprawira, Sjafri. 2001, Manajemen Sumber Daya ManusiaStrategik. Cet.1 Ed.2. Bogor : Penerbit Galih Indonesia.

Mulyasa. 2010. Menjadi Guru Profesional (Menciptakan Pembelajaran Kreatif dan Menyenangkan). Cetakan kesembilan, Bandung : Rosda Karya.

Rivai, Veithzal. 2009. Manajemen Sumber Daya Manusia Untuk Perusahaan dan Teori - Praktek. Jakarta : Raja Grafindo Persada.

Solichin, M Ridho. Pengaruh Kepuasan Kerja dan Stres Kerja Terhadap kinerja guru dalam meningkatkan mutu akademik lulusan pada SMA RSBI di Kabupaten Sidoarjo. 2013. Jurnal Ekonomi dan Kewirausahaan, Vo. 1 No. $1: 14-25$.

Soedijarto. 2011. Manajemen Kinerja dan Penjamin Mutu Pendidikan (Teori dan Praktik). Bandung : Remaja Rosdakarya

Suriani. 2020. Pengaruh Komitmen Organisasi, Profesionalisme dan Kompetensi Guru Terhadap Kinerja Guru di SMPN I VIDI Kab. Aceh Timur. Jurnal Ekonomi Keuangan dan Kebijakan Publik. Vol.2 No. 1.

Gibson dan Donely. 1994. Organisasi dan Manajemen, Perilaku, Struktur dan Proses : Edisi Keempat. Jakarta : Erlangga.

Hasibuan, Malayu S.P. 2002. Manajemen Sumber Daya Manusia : Cetakan Kelima. Jakarta : PT. Bumi Aksara.

Moorhead, G dan Griffin, R.W. 1996. Organization Behavior, A Management Challeng. Chicago : The Dryden Press. .

Mowday, RT dan Porter LW. 1979. The Measurement of Organizational Commitment. Journal of Vocational Behavior. Vol. 14 : 24 - 33.

Mathis, R. L dan J. H, Jackson. 2006. Human Resource Management : Manajemen Sumber Daya Manusia. Terjemahan Dian Angelia, Jakarta : Salemba Empat.

Mangkunegara, Anwar Prabu. 2002. Manajemen Sumber Daya Manusia. Bandung : Remaja Rosdakarya.

Steers, R.M dan Porter, L.W. 2000. Motivation and Work Behavior, New York: Acadaemic Press.

Rivai, Veithzal. 2009. Manajemen Sumber Daya Manusia Untuk Perusahaan dan Teori - Praktek. Jakarta : Raja Grafindo Persada. 
Robbin, Stephen P. 2006. Perilaku Organisasi :

Edisi Ke-10. PT. Indeks : Kelompok Gramedia. 